\title{
Influence of Mechanical String Thinning Treatments on Vegetative and Reproductive Tissues, Fruit Set, Yield, and Fruit Quality of 'Gala' Apple
}

\author{
Thomas M. Kon ${ }^{1}$, James R. Schupp, H. Edwin Winzeler, \\ and Richard P. Marini \\ Department of Horticulture, Pennsylvania State Fruit Research and \\ Extension Center, 290 University Drive, Biglerville, PA 17307
}

Additional index words. blossom thinner, crop load management, Malus $\times$ domestica, organic thinner, partial defoliation, spur leaf injury

\begin{abstract}
The objectives of this experiment were to test the efficacy of a mechanical string thinner (Darwin PT-250; Fruit-Tec, Deggenhauserertal, Germany) on apple and to identify an optimal range of thinning severity as influenced by spindle rotation speed. Trials were conducted in 2010 and 2011 at the Pennsylvania State University Fruit Research and Extension Center in Biglerville, PA, on five-year-old 'Buckeye Gala'/M.9 apple trees that were trained to tall spindle. A preliminary trail on five-year-old ' $\mathrm{Cripps}$ Pink'/M.9 was conducted to determine the relationship between string number and thinning severity. As the number of strings increased, the level of thinning severity increased. A range of spindle speeds ( 0 to $300 \mathrm{rpm}$ ) was applied to the same trees for two consecutive years. As spindle speed increased, blossom density (blossom clusters per limb cross-sectional area) was reduced as was the number of blossoms per spur. In 2010, leaf area per spur was reduced $9 \%$ to $45 \%$. In 2011 , the fastest spindle speed reduced leaf area per spur $\mathbf{2 0} \%$. Although increased spindle speed reduced cropload, injury to spur leaves may have inhibited increases in fruit size. The largest gain in fruit weight was $\mathbf{2 8} \mathrm{g}$ $(300 \mathrm{rpm})$ compared with the control. In both years, the most severe thinning treatments reduced yield by more than $50 \%$. There was no relationship between spindle speed and return bloom. Severe thinning treatments $(240$ to $300 \mathrm{rpm})$ caused significant reductions in spur leaf area, yield, and fruit calcium and did not improve fruit size or return bloom. Spindle speeds of 180 and $210 \mathrm{rpm}$ provided the best overall thinning response and minimized injury to spur leaves, but cropload reduction was insufficient in years of heavy fruit set. Therefore, mechanical blossom thinning treatments should be supplemented with other thinning methods. Mechanical string thinning may be a viable treatment in organic apple production, where use of chemical thinners is limited.
\end{abstract}

Mechanical methods of thinning fruit trees such as high-pressure spray guns, tree shakers, club thinning, rope thinners, drum shakers, and string thinners can produce a thinning response in stone fruits and some nut crops (Dennis, 2000). There has been limited adoption of mechanical thinning practices in apple as a result of two primary factors: 1) the damage and removal of spurs; and 2) the potential to spread the fireblight pathogen Erwina amylovora.

\footnotetext{
Received for publication 11 July 2012. Accepted for publication 10 Oct. 2012.

This project was funded by the Penn State Horticulture Department, USDA SCRI: Innovative Technologies for Thinning of Fruit, and the State Horticultural Association of Pennsylvania.

We thank the following for their contributions to this project: Eric Anderson, John P. Baugher, Larry Hull, Celine Kuntz, Evan Moore, David Rostad, Jen Rouzer, Terry Salada, Martha Schupp, Melanie Schupp, and Freeman Showers. Appreciation is extended to Kathy Brown and Paul Heinemann for critical review of the manuscript.

${ }^{1}$ To whom reprint requests should be addressed; e-mailtmk243@psu.edu.
}

In apple, primary spur leaves emerge before anthesis and can be damaged by physical disturbance. Ferree and Palmer (1982) showed the importance of spur leaf area on young fruit development and retention. As illustrated by Ngugi and Schupp (2009), mechanical thinners can also be an efficient vector of fireblight. Precautions are advised when using the string thinner on apple such as the use of predictive models to forecast the risk of infection, avoiding use of the string thinner in blocks with a history of fireblight, and the use of an antibiotic post-treatment if conditions are conducive for fireblight infection (Ngugi and Schupp, 2009).

Recent mechanical thinning investigations on apple have used two different thinning machines and have shown good efficacy (Bertschinger et al., 1998; Damerow et al., 2007). Thinning with the Darwin (Fruit-Tec, Deggenhauserertal, Germany) string thinner reduced fruit set by $25 \%$, enhanced return bloom when compared with the control, and did not significantly injure foliage (Weibel et al., 2008). A 50\% increase in mean fruit weight, improved fruit color, and a reduction in follow-up hand-thinning time were demonstrated by Sinatsch et al. (2010). The impacts of spur leaf reduction resulting from mechanical thinning were examined by Solomakhin and Blanke (2010), but leaves were only considered damaged if one-third or more of the lamina was removed. At $320 \mathrm{rpm}$ with a three-rotor string thinner (the Bonner, University of Bonn, Germany), less than $8 \%$ of leaves were injured while providing acceptable thinning efficacy. Trials in Germany with a three-rotor string thinner resulted in a $25-\mathrm{g}$ increase in mean fruit weight, reduced yield, and enhanced packout by $20 \%$ when compared with an unthinned control (Veal et al., 2011).

The objectives of this study were to evaluate the efficacy of a single spindle string thinner on apple in the mid-Atlantic region, determine the influence of string number on thinning severity, and identify an optimal range of spindle speeds.

\section{Materials and Methods}

Influence of string number on thinning severity. A trial was conducted in the spring of 2010 at the Pennsylvania State University Fruit Research and Extension Center in Biglerville, PA, on five-year-old 'Cripps Pink'/ M.9 apple trees at $1.2 \times 4.6-\mathrm{m}$ spacing. The trees were trained to a vertical axis system with an average tree height of $\approx 4.0 \mathrm{~m}$ and canopy width at the lower scaffolds of $\approx 1.5 \mathrm{~m}$. The trees were conical in shape, and lower limbs were somewhat rigid. The experiment was a randomized complete block design with five replications consisting of five tree plots. Two data trees were selected within the center of each plot to ensure consistent treatment and tree uniformity. A third tree from the interior of the plot was designated to quantify the removal of reproductive and vegetative tissues.

All treatments were applied at full bloom with a Darwin PT-250 mechanical string thinner (Fig. 1). A description of the machine is provided in Schupp et al. (2008). Forward speed and spindle speed were held constant in all treatments $\left(4.8 \mathrm{~km} \cdot \mathrm{h}^{-1}\right.$ and $240 \mathrm{rpm}$, respectively). Treatments were applied as follows: 1) unthinned control; 2) 90 strings; 3) 180 strings; and 4) 270 strings per $2.5-\mathrm{m}$ spindle length. The string thinner was fitted with 30 plates of strings with three, six, or nine $61.5-\mathrm{cm}$ strings affixed to each plate. In Treatments 3 and 4, gaps between strings were evenly distributed along the spindle.

Fruit set was evaluated on two to three limbs of the data trees. Before treatment, the initial number of blossom clusters per flagged limb was recorded and limb circumferences were measured to calculate limb crosssectional area (LCSA). Immediately after treatment, blossom clusters were counted on the sample limbs. Ten spurs were excised from two-year-old wood in one tree of each plot. The number of flowers, leaves, and leaf area per spur were quantified. If the ovary was visibly injured by the string thinner, it was assumed to be incapable of fertilization and was not counted. A LI-COR 3100 leaf 


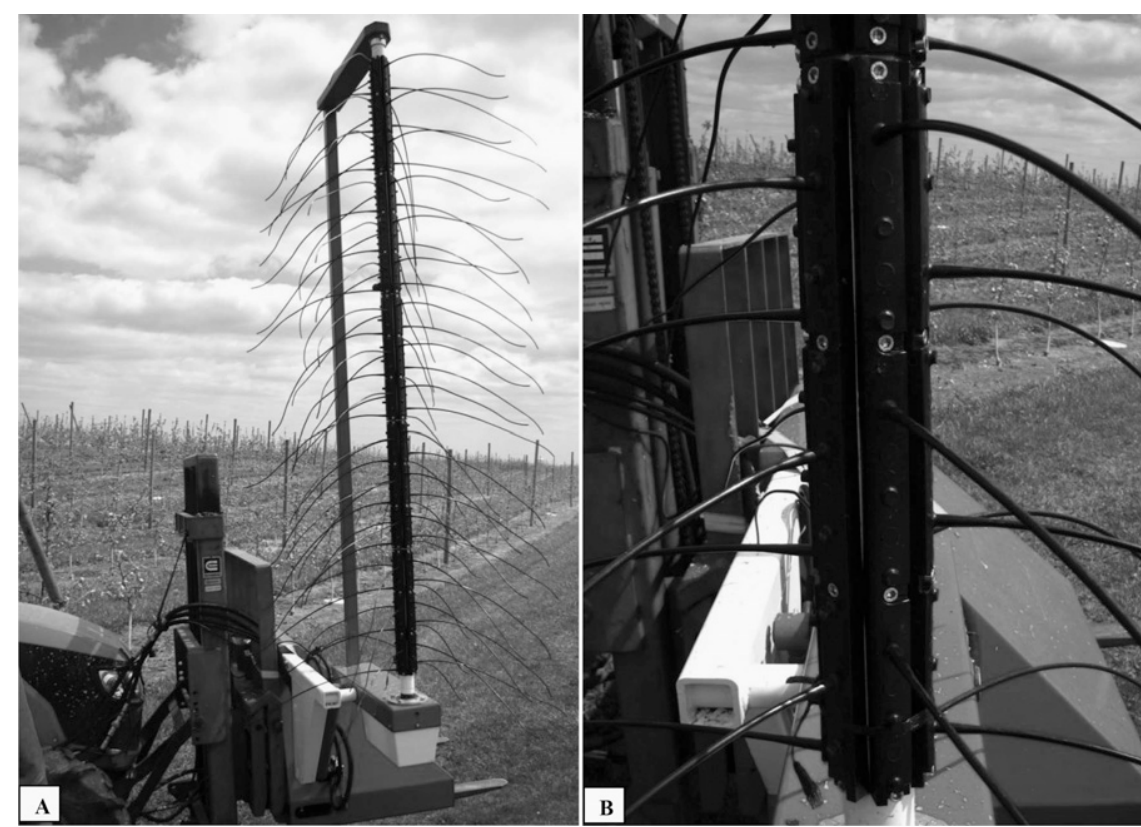

Fig. 1. (A) The Darwin PT-250 with (B) the helical string pattern. A total of 90 strings were attached to the 2.5-m spindle.

area meter (LI-COR, Lincoln, NE) was used to determine the leaf area per spur. Leaf number per $\mathrm{cm}^{2}$ LCSA was calculated by multiplying the number of clusters per $\mathrm{cm}^{2}$ LCSA persisting after treatment by the average number of leaves per sampled spur. Leaf area per $\mathrm{cm}^{2}$ LCSA was calculated by multiplying the number of clusters per $\mathrm{cm}^{2}$ LCSA persisting after treatment by the leaf area per spur. Fruit set was determined after June drop. $A \approx 20-\mathrm{kg}$ sample was collected at harvest to determine mean fruit weight.

Influence of spindle speed on thinning severity. Experiments were conducted in the spring of 2010 and 2011 on five-year-old 'Buckeye Gala'/M.9 apple trees at $1.2 \times 4.6-\mathrm{m}$ spacing. Trees were trained to a tall spindle with an average tree height of $\approx 4.0 \mathrm{~m}$ and canopy width of $\approx 1.5 \mathrm{~m}$. The shape of the canopy was a narrow tree wall. The experiment was a randomized complete block design with four replications. Treatments were applied to eight tree plots. The first and last trees in each plot were not used for data collection, because they may have been subjected to an irregular thinning treatment. Two data trees were selected within the center six trees of the eight tree plot to ensure consistent treatment and tree uniformity.

Treatments were applied as follows: 1) unthinned control; 2) string thinned at $180 \mathrm{rpm}$; 3) string thinned at $210 \mathrm{rpm}$; 4) string thinned at $240 \mathrm{rpm}$; 5) string thinned at $270 \mathrm{rpm}$; and 6) string thinned at $300 \mathrm{rpm}$. Spindle speeds were verified with a digital tachometer before treatment (CDT-1000HD; Albuquerque Inc., Briarwood, NY). All treatments were applied at full bloom with a Darwin PT-250 mechanical string thinner. Forward speed was constant at $4.8 \mathrm{~km} \cdot \mathrm{h}^{-1}$. A helical string pattern comprised of 90 strings was used because this treatment minimized vegetative damage. The helical string pattern was created by using 30 plates of strings with three $61.5-\mathrm{cm}$ strings attached to each plate. To obtain information about the cumulative effects of mechanical thinning of apple, the same treatments were reapplied to the plots both years.

Two to three limbs per data tree were flagged and measured, and blossom clusters were counted as described for the previous experiment (two trees per plot, 48 trees total). Lateral blossom clusters were included in these counts as a result of the propensity of these clusters to set fruit and contribute to cropload and yield. Trunk circumferences were measured $30 \mathrm{~cm}$ above the graft union, and initial trunk cross-sectional area (TCSA) was calculated. Two additional trees from the interior six trees of each plot were designated to quantify the removal of reproductive and vegetative tissues. The two trees selected for quantifying leaf and blossom removal were not used for these counts. Immediately after treatment, 10 spurs were excised from twoyear-old wood in each plot. Spur analysis was conducted as described in the previous experiment.

Spur removal was evaluated on the same day that treatments were applied. Beginning $8 \mathrm{~d}$ after treatment, individual fruitlets on flagged limbs were counted at 3- to 4-d intervals to observe fruitlet abscission patterns of all treatments. Once fruitlet numbers remained constant for a period of 1 week, final fruit set was assessed on flagged limbs. In 2011, diameters of 10 fruitlets per plot were measured at each date that fruitlet counts were conducted.

In 2010 an outbreak of wooly apple aphids (Eriosoma lanigerum) appeared to be correlated with thinning treatment. The number of wooly apple aphid colonies per plot was estimated by a 4-min count of the six center trees of each plot on 16 June.
Whole tree yields, mean fruit weight, and fruit size distribution of two trees per plot were determined with an electronic fruit sorter (Durand Wayland, LaGrange, GA). When the trees were dormant, the trunk diameters were recorded and TCSA was calculated. Return bloom was evaluated by selecting four representative limbs per two tree plot and counting the number of blossom clusters per limb. Cluster counts were expressed per $\mathrm{cm}^{2}$ LCSA.

At harvest, 20 fruit per plot between 125 and $175 \mathrm{~g}$ were sampled for postharvest quality analysis. Fruit firmness was measured with a Güss GS-14 penetrometer (QA Supplies LLC, Norfolk, VA). Juice samples were collected and tested for soluble solids concentration with a digital refractometer (model PR-32 $\alpha$; Atago, Bellevue, WA). Fifteen-milliliter juice samples were extracted with a juicer and tested for $\mathrm{pH}$ and titratable acidity (malic acid equivalents) with an automatic minititrator and $\mathrm{pH}$ meter (Model HI-84432; Hanna Instruments, Woonsocket, RI).

In 2011, a sample of 20 fruits from each plot were cut at the equator and dipped in an iodine solution. Based on staining patterns, each fruit was assigned a value from 1 to 8 in accordance with the Generic Cornell StarchIodine Index Chart for apples (Blanpied and Silsby, 1992). An additional 10-fruit sample was used to quantify internal ethylene concentration. Internal ethylene of whole fruit samples was collected through vacuum extraction (Saltveit, 1982). One-milliliter gas samples were injected into a gas chromatograph (GC-8A; Shimadzu, Columbia, MD) with a $1 / 8$-in. stainless steel column packed with alumina (Supelco, Bellefonte, PA).

An additional 20-fruit sample of 125 to $175 \mathrm{~g}$ fruits from each plot was collected to analyze mineral content. A $1.0-\mathrm{cm}$ equatorial slice of fruit tissue was made, and four circular plugs were cut with a $1.0-\mathrm{cm}$ cork borer. The circular plugs of cortical tissue were removed near the epidermis of the fruit and dried in a freeze dryer (Labconoco, Kansas City, MO). The samples were then ground until the tissue was macerated to less than 20 mesh $(0.853 \mathrm{~mm})$. Samples were sent to the Penn State Agricultural Analytical Services Laboratory (University Park, PA) for mineral analysis. Mineral content of samples was analyzed for phosphorus, potassium, calcium, magnesium, manganese, iron, copper, boron, aluminum, zinc, sodium, and sulfur through automated hot block acid digestion (Huang and Schulte, 1985).

The PC version of SAS (Version 9.3; SAS Institute, Cary, NC) was used for all statistical analysis. Linear and quadratic relationships of plot means were evaluated with the mixed procedure (PROC MIXED).

\section{Results and Discussion}

Influence of string number on thinning severity. Publications regarding string thinning of apple used the maximum number of 
Table 1. Effect of string number on reproductive tissues, vegetative tissues, fruit set, and mean fruit weight of 'Cripps Pink'/M.9 apple trees in 2010. ,v

\begin{tabular}{|c|c|c|c|c|c|c|c|c|}
\hline $\begin{array}{l}\text { String } \\
\text { number }\end{array}$ & $\begin{array}{l}\text { Clusters removed } \\
\text { per LCSA }{ }^{y}\end{array}$ & $\begin{array}{c}\text { No. of blossoms } \\
\text { per spur }\end{array}$ & $\begin{array}{c}\text { No. of leaves } \\
\text { per spur }\end{array}$ & $\begin{array}{l}\text { No. of leaves } \\
\text { per LCSA }\end{array}$ & $\begin{array}{c}\text { Leaf area } \\
\text { per spur }\left(\mathrm{cm}^{2}\right)^{x}\end{array}$ & $\begin{array}{c}\text { Leaf area } \\
\text { per } \operatorname{LCSA}\left(\mathrm{cm}^{2}\right)^{\mathrm{w}}\end{array}$ & $\begin{array}{c}\text { Fruit set } \\
\left(\text { fruit } / \mathrm{cm}^{2}\right)^{y}\end{array}$ & $\begin{array}{l}\text { Fruit } \\
\text { wt (g) }\end{array}$ \\
\hline$\overline{0}$ & 0.0 & 4.6 & 8.2 & 73 & 47.4 & 420 & 8.9 & 170.0 \\
\hline 90 & 4.6 & 3.1 & 6.6 & 51 & 27.9 & 220 & 4.6 & 186.8 \\
\hline 180 & 5.5 & 2.4 & 6.6 & 42 & 21.0 & 141 & 4.9 & 189.9 \\
\hline 270 & 7.5 & 2.1 & 4.2 & 26 & 18.2 & 99 & 2.7 & 186.5 \\
\hline \multicolumn{9}{|l|}{ Significance } \\
\hline Linear & $<0.0001$ & $<0.0001$ & 0.0005 & 0.0004 & 0.0002 & 0.0003 & 0.0055 & 0.0037 \\
\hline Quadratic & 0.1267 & 0.0019 & 0.5604 & 0.7042 & 0.0218 & 0.0741 & 0.3976 & $<0.0001$ \\
\hline
\end{tabular}

${ }^{\mathrm{z}}$ Means of eight observations.

${ }^{\mathrm{y}} \mathrm{LCSA}=$ limb cross-sectional area $\left(\mathrm{cm}^{2}\right)$

${ }^{x}$ Means of 50 harvested spurs per treatment $(n=4)$.

wThese values were attained by multiplying leaf no. or leaf area per spur by the number of clusters remaining per LCSA. Leaf area and leaf no. per spur did not account for the reduction in leaf area and leaf no. from the blossom clusters that were removed.

vreatments were applied at a tractor speed of $4.8 \mathrm{~km} \cdot \mathrm{h}^{-1}$ and a spindle speed of $240 \mathrm{rpm}$.

strings in their trials or do not mention the number of strings used. In peach, the optimum number of strings used is a fraction of the total possible number of strings (Baugher et al., 2009). Higher numbers of strings increased the level of thinning severity in apple. Increased string number caused more string contact with the canopy and increased damage to reproductive and vegetative structures (Table 1). Leaf area per spur was reduced $41 \%$ to $62 \%$ and leaf area per LCSA was reduced $48 \%$ to $76 \%$ when compared with the control. Using 180 strings resulted in the highest fruit weight, but there was less than a 4-g difference in mean fruit weight across trees subjected to mechanical thinning. Based on the results of this trial, the lowest tested string number was used in the subsequent experiment.

Influence of spindle speed on thinning severity. Most mechanical thinning studies have been one-year evaluations, and multiyear studies tested the effect of mechanical thinning treatments on multiple cultivars or used different plots (Dorigoni et al., 2008, 2010; Veal et al., 2011; Weibel et al., 2008). Because apple is a perennial crop, and mechanical thinning treatments affect the balance of vegetative and reproductive growth, we tested cumulative effects of differentially severe treatments over two consecutive years.

The removal of entire blossom clusters by mechanical string thinners has been described as an occasional occurrence and only typical of the first use in an orchard (Veal et al., 2011). In our study, the string thinner removed more blossom clusters in 2010 when compared with 2011 (Table 2). In other studies, increased spindle speeds removed a higher number of blossom clusters, and the most severe treatment $(320 \mathrm{rpm}$ at 2.5 $\mathrm{km} \cdot \mathrm{h}^{-1}$ ) removed 25 blossom clusters per tree (Damerow et al., 2007). Conversely, Sinatsch et al. (2010) reported no differences between severity treatments and the level of spur removal. We observed a curvilinear increase in removal of blossom clusters as spindle speed increased. High spindle speeds removed fruiting spurs on two- and threeyear-old wood and encouraged development of fruit on the periphery of the canopy. Lateral blooms, which often produce inferior fruit, remained after thinning treatment. By

Table 2. Effect of six spindle speeds on reproductive and vegetative tissues of 'Buckeye Gala'/M.9 apple trees in 2010 and 2011.

\begin{tabular}{|c|c|c|c|c|c|c|}
\hline $\begin{array}{l}\text { Spindle } \\
\text { speed (rpm) }\end{array}$ & $\begin{array}{l}\text { Clusters } \\
\text { removed } \\
\text { per LCSA }\end{array}$ & $\begin{array}{l}\text { No. of } \\
\text { blossoms } \\
\text { per spur }\end{array}$ & $\begin{array}{c}\text { No. of } \\
\text { leaves } \\
\text { per spur }\end{array}$ & $\begin{array}{c}\text { No. of } \\
\text { leaves } \\
\text { per LCSA }\end{array}$ & $\begin{array}{l}\text { Leaf area } \\
\text { per spur } \\
\left(\mathrm{cm}^{2}\right)\end{array}$ & $\begin{array}{c}\text { Leaf area } \\
\text { per LCSA } \\
\left(\mathrm{cm}^{2}\right)\end{array}$ \\
\hline & & & 2010 & & & \\
\hline 0 & 0.0 & 5.3 & 9.7 & 200 & 65.2 & 1335 \\
\hline 180 & 3.4 & 4.8 & 8.6 & 157 & 59.3 & 1122 \\
\hline 210 & 2.5 & 4.4 & 8.2 & 106 & 55.2 & 713 \\
\hline 240 & 7.2 & 3.5 & 7.1 & 83 & 36.9 & 420 \\
\hline 270 & 9.0 & 3.3 & 7.4 & 60 & 41.4 & 336 \\
\hline 300 & 10.5 & 2.7 & 7.3 & 65 & 36.0 & 317 \\
\hline \multicolumn{7}{|l|}{ Significance } \\
\hline Linear & $<0.0001$ & $<0.0001$ & $<0.0001$ & $<0.0001$ & 0.0020 & $<0.0001$ \\
\hline \multirow[t]{2}{*}{ Quadratic } & 0.0012 & 0.0010 & 0.6870 & 0.0878 & 0.0728 & 0.0452 \\
\hline & & & 2011 & & & \\
\hline 0 & 0.0 & 5.1 & 9.6 & 88 & 21.1 & 183 \\
\hline 180 & 0.5 & 4.6 & 10.2 & 115 & 26.9 & 229 \\
\hline 210 & 1.2 & 4.5 & 9.0 & 95 & 22.5 & 170 \\
\hline 240 & 2.0 & 4.0 & 8.8 & 86 & 19.8 & 197 \\
\hline 270 & 4.2 & 4.1 & 8.9 & 67 & 19.3 & 122 \\
\hline 300 & 7.1 & 3.3 & 8.3 & 50 & 16.9 & 103 \\
\hline \multicolumn{7}{|l|}{ Significance } \\
\hline Linear & 0.0004 & $<0.0001$ & 0.0770 & 0.1659 & 0.2400 & 0.1184 \\
\hline Quadratic & $<0.0001$ & 0.0210 & 0.0710 & 0.0055 & 0.0051 & 0.0089 \\
\hline
\end{tabular}

${ }^{2}$ Means of six observations.

${ }^{y}$ LCSA $=$ limb cross-sectional area $\left(\mathrm{cm}^{2}\right)$.

${ }^{x}$ Means of 40 harvested spurs per treatment $(n=6)$.

wThese values were attained by multiplying leaf no. or leaf area per spur by the number of clusters remaining per LCSA. Leaf area and leaf no. per spur did not account for the reduction in leaf area and leaf no. from the blossom clusters that were removed entirely.

removing spurs, the string thinner inadvertently selected for lateral blossom clusters. This may in part explain why increased spindle speed did not improve fruit weight in 2011 (Table 3).

In previous string thinning studies, treatments generally removed less than one blossom on average from each blossom cluster in the recommend range of treatments (Solomakhin and Blanke, 2010). We observed similar results at 180 and $210 \mathrm{rpm}$ (Table 2), but as spindle speed increased, greater contact with the canopy resulted in increased blossom removal. Similarly, Kong et al. (2009) and Strimmer and Kelderer (1997) observed damage to leaves, bark, and wood from the string thinner. Likewise, shoot and bud damage increased with higher spindle speeds (Solomakhin and Blanke, 2010). Damage to the bark, shoots, and buds was observed in our trial but was not formally quantified. As described previously
(Bertschinger et al., 1998), we observed a curvilinear increase in wooly apple aphid colonies after mechanical thinning treatments, perhaps as a result of conditions favorable to wooly apple aphids, namely increased bark damage (Table 3 ).

The observed reduction in spur leaf area with increasing spindle speed accords with several other studies. Solomakhin and Blanke (2010) reported a significant increase in leaf injury, because $10 \%$ to $42 \%$ of 'Gala' leaves and $15 \%$ to $32 \%$ of 'Golden Delicious' leaves were injured per limb with increased string thinning severity. However, leaves were only considered to be injured if more than onethird of the lamina was removed. With a similar set of treatments to Solomakhin and Blanke (2010), Damerow et al. (2007) and Veal et al. (2011) reported that a maximum of $8 \%$ of leaves were injured and Kong et al. (2009) reported that leaf damage was less than $10 \%$. We found leaf area per $\mathrm{cm}^{2}$ of 
Table 3. Effect of six spindle speeds on fruit set, WAA colonies, crop density, yield per tree, yield efficiency, trunk growth, fruit weight, and return bloom on 'Buckeye Gala'/M.9 apple trees in 2010 and 2011.'

\begin{tabular}{|c|c|c|c|c|c|c|c|c|}
\hline $\begin{array}{l}\text { Spindle } \\
\text { speed (rpm) }\end{array}$ & $\begin{array}{c}\text { Fruit set } \\
\text { (fruit/LCSA) }^{y}\end{array}$ & $\begin{array}{c}\text { No. of WAA } \\
\text { colonies per plot }^{\mathrm{x}}\end{array}$ & $\begin{array}{l}\text { Crop density } \\
\text { (fruit/TCSA)w }^{\text {f }}\end{array}$ & $\begin{array}{l}\text { Yield per } \\
\text { tree }(\mathrm{kg})\end{array}$ & $\begin{array}{l}\text { Yield efficiency } \\
\qquad\left(\mathrm{kg} / \mathrm{cm}^{2}\right)^{\mathrm{v}}\end{array}$ & $\begin{array}{l}\text { Trunk growth } \\
\left(\mathrm{cm}^{2}\right)\end{array}$ & $\begin{array}{c}\text { Fruit } \\
\text { wt (g) }\end{array}$ & $\begin{array}{l}\text { Return bloom } \\
(\mathrm{Bl} / \mathrm{LCSA})^{\mathrm{u}}\end{array}$ \\
\hline & & & & 2010 & & & & \\
\hline 0 & 11.2 & 20.5 & 13.8 & 35.0 & 1.6 & 1.6 & 121 & 9.1 \\
\hline 180 & 8.1 & 27.8 & 9.6 & 32.7 & 1.2 & 2.0 & 127 & 11.1 \\
\hline 210 & 6.2 & 28.5 & 9.1 & 26.5 & 1.2 & 2.0 & 128 & 11.1 \\
\hline 240 & 3.9 & 44.3 & 7.8 & 23.7 & 1.1 & 2.3 & 134 & 11.3 \\
\hline 270 & 2.8 & 49 & 7.8 & 20.6 & 0.9 & 2.4 & 137 & 11.5 \\
\hline 300 & 2.3 & 54.5 & 4.6 & 16.3 & 0.7 & 2.7 & 149 & 12.9 \\
\hline \multicolumn{9}{|l|}{ Significance } \\
\hline Linear & $<0.0001$ & 0.0006 & $<0.0001$ & $<0.0001$ & $<0.0001$ & 0.0006 & 0.0073 & 0.0778 \\
\hline \multirow[t]{2}{*}{ Quadratic } & 0.0589 & 0.0272 & 0.2423 & 0.0047 & 0.0149 & 0.0803 & 0.1251 & 0.8039 \\
\hline & & & & 2011 & & & & \\
\hline 0 & 6.7 & - & 7.6 & 26.5 & 1.2 & 3.8 & 170 & 16.1 \\
\hline 180 & 4.1 & - & 3.7 & 18.1 & 0.6 & 4.7 & 174 & 18.5 \\
\hline 210 & 3.7 & - & 3.5 & 14.4 & 0.6 & 5.1 & 179 & 14.6 \\
\hline 240 & 2.6 & - & 2.6 & 11.6 & 0.5 & 5.7 & 173 & 20.2 \\
\hline 270 & 1.4 & - & 2.8 & 11.4 & 0.5 & 4.9 & 177 & 20.3 \\
\hline 300 & 1.0 & - & 1.5 & 7.1 & 0.3 & 5.0 & 176 & 16.7 \\
\hline \multicolumn{9}{|l|}{ Significance } \\
\hline Linear & $<0.0001$ & - & $<0.0001$ & $<0.0001$ & $<0.0001$ & 0.0168 & 0.5318 & 0.4349 \\
\hline Quadratic & 0.2314 & - & 0.7775 & 0.1970 & 0.9533 & 0.3067 & 0.8402 & 0.9116 \\
\hline
\end{tabular}

${ }^{\mathrm{z}}$ Means of eight observations.

${ }^{\mathrm{y}}$ Fruit/LCSA $=$ total number of fruit per $\mathrm{cm}^{2}$ limb cross-sectional area.

${ }^{\mathrm{x}}$ Mean number of WAA (Eriosoma lanigerum) colonies determined in a 4-min count of a six-tree plot $(\mathrm{n}=24)$.

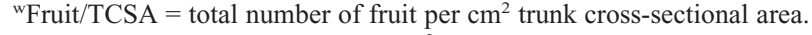

${ }^{v}$ Yield efficiency $=$ yield $(\mathrm{kg})$ per $\mathrm{cm}^{2}$ trunk cross-sectional area.

"B1/LCSA = total number of blossom clusters per $\mathrm{cm}^{2}$ limb cross-sectional area.

LCSA was reduced by $16 \%$ to $74 \%$ in 2010 and up to $46 \%$ in 2011 with a curvilinear decrease in leaf area per $\mathrm{cm}^{2}$ as spindle speed increased. Our studies quantified spur leaf injury with a leaf area meter, rather than visual ratings or counts, suggesting that previous studies may have underestimated leaf damage. Because one of our objectives was to identify an effective range of treatments, we designed an experiment with a wide range of spindle speeds. It was expected that some of the fastest spindle speeds might cause excessive damage. The bulk of mechanical thinning experiments have been designed to separate the means of various treatments, rather than evaluate relationship of thinning severity on selected response variables.

There were two major concomitant waves of fruit drop in all treatments (Fig. 2). In general, the control treatment had a higher abscission rate than the majority of the mechanical thinning treatments. The major period of drop in 2010 appeared to peak almost immediately after bloom. In 2011 the main period of drop occurred between $9.1 \mathrm{~mm}$ and $15.5 \mathrm{~mm}$ fruit diameter. Low crop levels in 2011 were probably a result of a period of carbon stress attributable to extended low light conditions that occurred between 16 and $21 \mathrm{~d}$ after full bloom (101 to 130 growing degree-days after full bloom; Fig. 2), resulting in a wave of fruitlet abscission. Although mechanical thinning can provide predictable rates of blossom removal, environmental conditions at bloom and post-bloom can influence final fruit set. The uncertainty of final fruit set is a valid concern for growers considering blossom thinning. In peach blossom-thinning trials, the goal is to partially adjust cropload to reduce the risk of overthinning (Schupp et al., 2008).
A

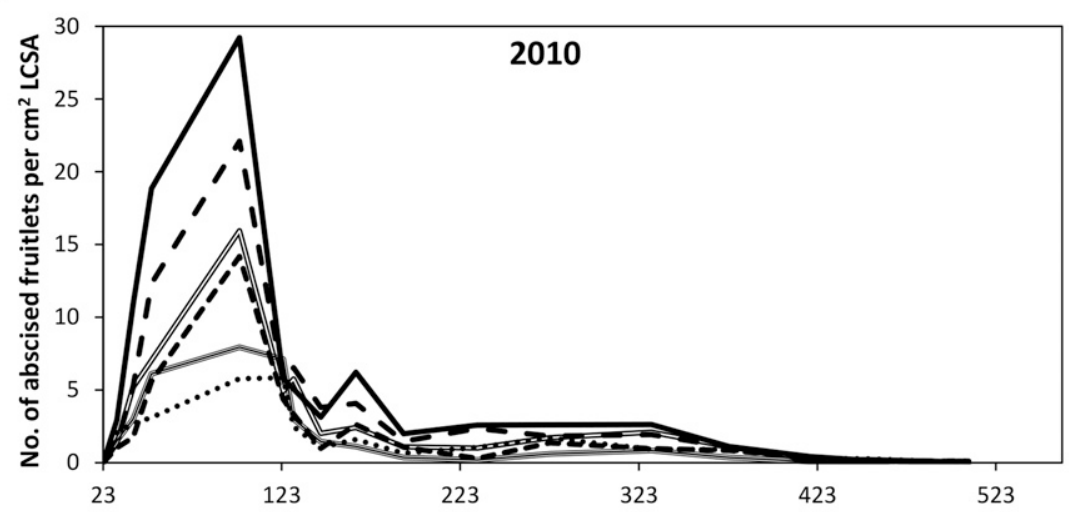

B

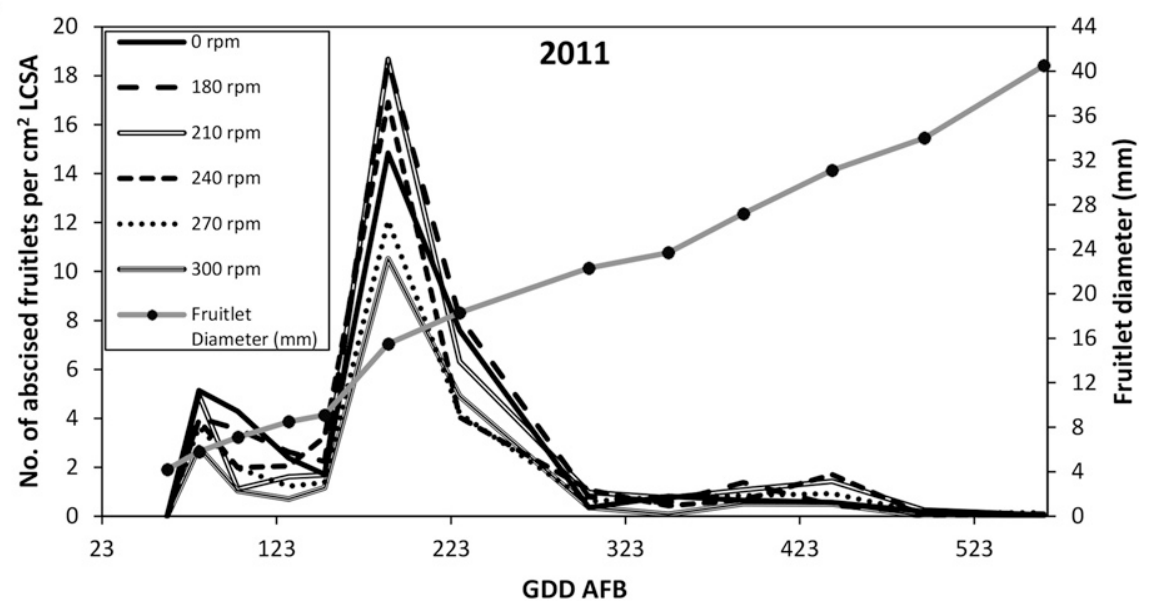

Fig. 2. Effect of six spindle speeds on patterns of fruitlet abscission per $\mathrm{cm}^{2}$ limb cross-sectional area (LCSA) in 2010 and 2011 (A and B, respectively). Measurements began $8 \mathrm{~d}$ after treatment (full bloom) and were conducted until final fruit set. Average fruitlet diameter was determined in 2011 by measuring 10 randomly selected fruitlets per plot $(n=24)$. GDD AFB is the calculated growing degrees after full bloom, base 10. Weather data were collected with a data logger (CR10X; Campbell Scientific, Logan, UT). 
If a similar strategy were adopted in apple, perhaps the lower spindle speeds we tested may be a valid tactic when thinning high-value apple cultivars.

Mechanical thinning reduced fruit set, the number of fruit per tree, and crop density of apple when compared with control treatments in several other studies (see Table 5). Fruit set and crop density declined linearly as spindle speed increased in both years of our study (Table 3 ). In 2010, control trees had a crop density of 13.8 fruit per $\mathrm{cm}^{2}$ of TCSA, which is considered supraoptimal (Table 3 ). Trees subjected to spindle speeds of 240 and $270 \mathrm{rpm}$ had a crop density of 7.8 fruit per $\mathrm{cm}^{2}$ in 2010 , which is within the ideal range of a commercial crop for 'Gala' (six to eight fruit per $\mathrm{cm}^{2}$ ). In 2011, the unthinned control had a mean crop density of 7.6 fruit per $\mathrm{cm}^{2}$ of TCSA. This is nearly an ideal cropload to produce a commercial crop, and all thinning treatments in 2011 resulted in overthinning.

Several authors have observed reductions in yield with increased string thinning severity (Dorigoni et al., 2008, 2010; Hehnen et al., 2012; Kong et al., 2009; Schupp et al., 2008; Solomakhin and Blanke, 2010). However, others have not observed significant reductions in yield as thinning severity is increased (Damerow et al., 2007; Dorigoni et al., 2008; Sinatsch et al., 2010; Strimmer and Kelderer, 1997; Veal et al., 2011), and in some cases, there is not a discernible pattern between thinning severity and yields. Our trials show that as spindle speed increases, there is a sharp reduction in yield (Table 3 ). High spindle speeds reduced yield by more than $50 \%$ in both years. A minor reduction in yield may be acceptable if fruit size was increased to an economically stimulating level. There are incentives in the market for growers to produce large 'Gala'; however, none of the mechanical thinning treatments substantially enhanced fruit size (Fig. 3).

'Gala' was selected for this study because it is a small-fruited cultivar that might benefit from early thinning. Despite removing a high percentage of reproductive sinks early in the season, mean fruit weight did not increase substantially in 2010 or 2011 . Although an increase in fruit weight was observed in 2010 , the practical implications of this increase are negligible (Table 3). A modest 28-g increase in fruit weight was the highest margin of increase in our two-year trial. Several authors described increases in fruit weight or fruit size as thinning severity increased (see Table 5). However, many of these reports presented data that included follow-up hand thinning as part of the treatment. Spur leaves are important to fruit growth (Ferree and Palmer, 1982), and injury to spur leaves has been shown to slow fruitlet growth early in the season (Yuan and Greene, 2000). Because fruit weight was not increased in our trial, we propose that the injury of spur leaves impacted the final fruit size of apple.

Return bloom was increased by using mechanical thinning treatments in several studies (Dorigoni et al., 2010; Strimmer and
A

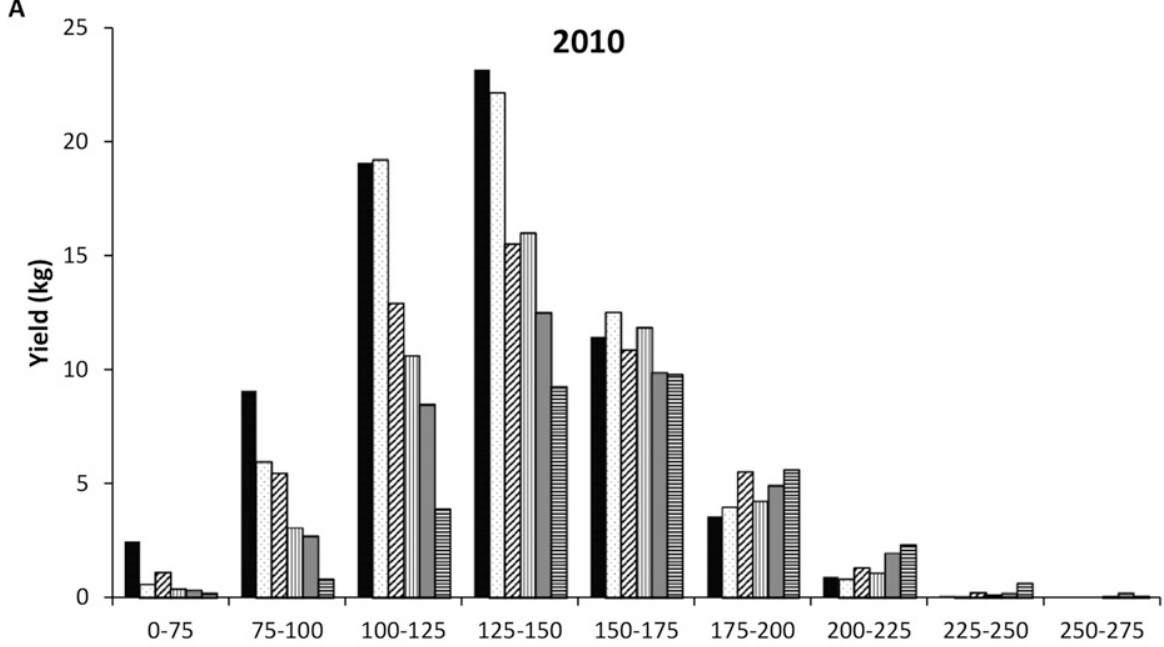

B

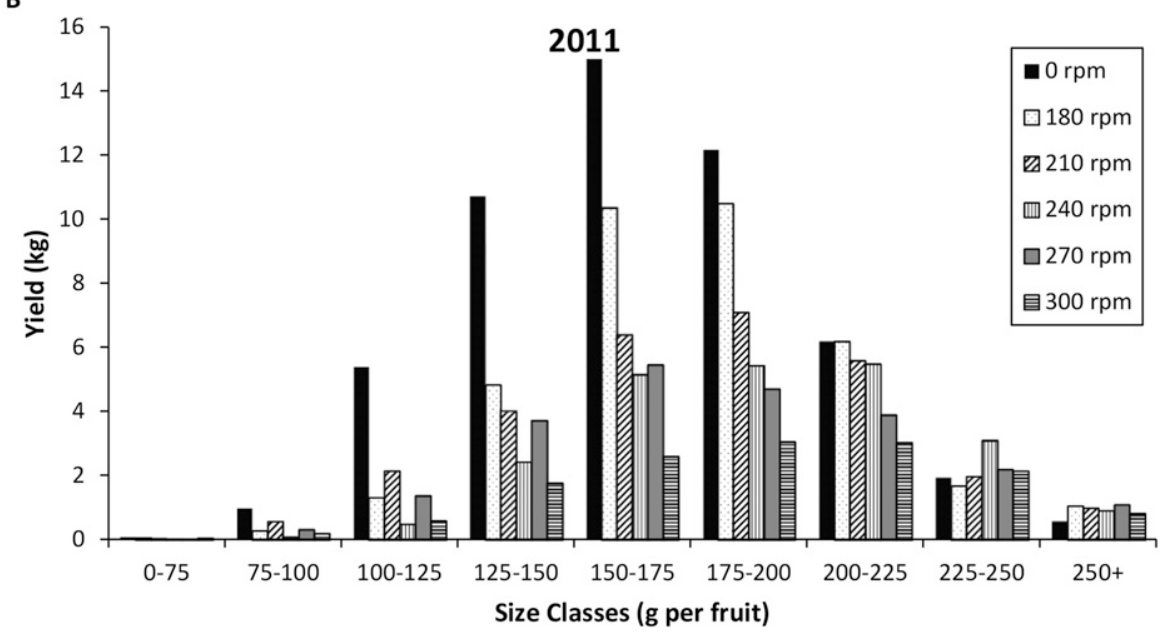

Fig. 3. Effect of six spindle speeds on fruit size distribution in 2010 and 2011 (A and $\mathbf{B}$, respectively). The data are expressed as mean weight $(\mathrm{kg})$ of 'Buckeye Gala' of a two tree plot $(\mathrm{n}=24,48$ trees total) in nine size classes $(\mathrm{g})$.

Table 4. Effect of six spindle speeds on firmness, soluble solids, titratable acidity, sugar to acid ratio, Ca concentration, and starch ratings of 'Buckeye Gala'/M.9 apples in 2010 and 2011. z,y

\begin{tabular}{|c|c|c|c|c|c|c|}
\hline $\begin{array}{l}\text { Spindle } \\
\text { speed (rpm) }\end{array}$ & $\begin{array}{c}\text { Fruit } \\
\text { firmness }(\mathrm{N})\end{array}$ & $\begin{array}{c}\text { Soluble } \\
\text { solids }(\%)\end{array}$ & $\begin{array}{c}\text { Titratable } \\
\text { acidity }(\%)^{\mathrm{x}}\end{array}$ & $\begin{array}{l}\text { Sugar to acid } \\
\text { ratio }(\mathrm{ss}: \mathrm{ma})^{\mathrm{x}}\end{array}$ & $\begin{array}{c}\text { Fruit Ca } \\
\text { concn }\left(\mathrm{mg} \cdot \mathrm{L}^{-1}\right)\end{array}$ & $\begin{array}{c}\text { Starch rating } \\
(1-8)\end{array}$ \\
\hline \multicolumn{7}{|c|}{2010} \\
\hline 0 & 73.1 & 14.6 & 0.30 & $49: 1$ & 339 & - \\
\hline 180 & 78.4 & 15.1 & 0.34 & $46: 1$ & 326 & - \\
\hline 210 & 80.5 & 15.3 & 0.32 & $49: 1$ & 274 & - \\
\hline 240 & 81.3 & 15.6 & 0.34 & $46: 1$ & 253 & - \\
\hline 270 & 83.2 & 16.6 & 0.40 & $42: 1$ & 244 & - \\
\hline 300 & 83.7 & 16.4 & 0.39 & $42: 1$ & 262 & - \\
\hline \multicolumn{7}{|l|}{ Significance } \\
\hline Linear & 0.0012 & 0.0002 & 0.0040 & 0.0693 & 0.0002 & - \\
\hline Quadratic & 0.3899 & 0.0159 & 0.0764 & 0.2694 & 0.3900 & - \\
\hline \multicolumn{7}{|c|}{2011} \\
\hline 0 & 94.6 & 13.4 & 0.31 & $43: 1$ & 208 & 6.0 \\
\hline 180 & 95.9 & 13.6 & 0.36 & $38: 1$ & 201 & 5.8 \\
\hline 210 & 96.8 & 14.0 & 0.39 & $36: 1$ & 201 & 5.8 \\
\hline 240 & 103.8 & 14.1 & 0.41 & $35: 1$ & 172 & 4.8 \\
\hline 270 & 103.3 & 14.2 & 0.42 & $34: 1$ & 165 & 4.8 \\
\hline 300 & 103.3 & 14.4 & 0.43 & $34: 1$ & 170 & 4.5 \\
\hline \multicolumn{7}{|l|}{ Significance } \\
\hline Linear & 0.0048 & 0.0010 & $<0.0001$ & $<0.0001$ & 0.0037 & 0.0029 \\
\hline Quadratic & 0.1445 & 0.1854 & 0.2411 & 0.9899 & 0.1011 & 0.0428 \\
\hline
\end{tabular}

${ }^{\mathrm{z}}$ Means of six observations.

${ }^{\mathrm{y}}$ Sample size of 20 fruit per plot. All fruit selected for postharvest analysis were 125 to $175 \mathrm{~g}$.

xercent malic acid was selected for analysis because it is the most abundant acid in apple.

$\mathrm{Ca}=$ calcium. 
Table 5. A summary of several recent mechanical thinning studies.

\begin{tabular}{|c|c|c|c|c|c|c|}
\hline Author & $\begin{array}{c}\text { Commercial } \\
\text { name }^{\mathrm{z}}\end{array}$ & Spindle and tractor speeds & $\begin{array}{l}\text { Reduced } \\
\text { fruit set }\end{array}$ & $\begin{array}{l}\text { Increased } \\
\text { fruit size }\end{array}$ & $\begin{array}{l}\text { Reduced } \\
\text { yield }\end{array}$ & $\begin{array}{l}\text { Increased } \\
\text { return bloom }\end{array}$ \\
\hline Dorigoni et al., 2008 & Darwin & $\begin{array}{l}300 \mathrm{rpm} \text { at } 9 \mathrm{~km} \cdot \mathrm{h}^{-1} \text { and } 320 \mathrm{rpm} \\
\text { at } 8 \mathrm{~km} \cdot \mathrm{h}^{-1}\end{array}$ & Yes & Yes & No & No \\
\hline Hehnen et al., 2012 & Bonner & 220 and $360 \mathrm{rpm}$ at $2.5 \mathrm{~km} \cdot \mathrm{h}^{-1}$ & Yes & Yes & Yes & No \\
\hline Kong et al., 2009 & Bonner & $\begin{array}{l}300-420 \mathrm{rpm} \text { at } 5 \mathrm{~km} \cdot \mathrm{h}^{-1} ; 300 \\
\text { to } 480 \mathrm{rpm} \text { at } 7.5 \mathrm{~km} \cdot \mathrm{h}^{-1}\end{array}$ & Yes & Yes & Yes & $\mathrm{NA}^{\mathrm{x}}$ \\
\hline $\begin{array}{l}\text { Solomakhin and Blanke, } \\
2010\end{array}$ & Bonner & $\begin{array}{l}300 \text { to } 420 \mathrm{rpm} \text { at } 5 \mathrm{~km} \cdot \mathrm{h}^{-1} ; 360 \\
\text { to } 480 \mathrm{rpm} \text { at } 7.5 \mathrm{~km} \cdot \mathrm{h}^{-1}\end{array}$ & Yes & Yes & Yes & NA \\
\hline Stadler et al., 1996 & Darwin & $4 \mathrm{~km} \cdot \mathrm{h}^{-1 \mathrm{w}}$ & Yes & NA & NA & NA \\
\hline $\begin{array}{l}\text { Strimmer and Kelderer, } \\
1997\end{array}$ & Darwin & $200 \mathrm{rpm}$ at 5,7 , and $8 \mathrm{~km} \cdot \mathrm{h}^{-1}$ & Yes & Yes & No & Yes \\
\hline Veal et al., 2011 & Bonner & 240 to $360 \mathrm{rpm}$ at $2.5,5$ and $7 \mathrm{~km} \cdot \mathrm{h}^{-1}$ & NA & $\mathrm{Yes}^{\mathrm{v}}$ & $\mathrm{No}^{\mathrm{v}}$ & $\mathrm{Yes}^{\mathrm{v}}$ \\
\hline Weibel et al., 2008 & Darwin & $300 \mathrm{rpm}$ at $10-12 \mathrm{~km} \cdot \mathrm{h}^{-1}$ & Yes & NA & NA & Yes \\
\hline
\end{tabular}

${ }^{2}$ See Schupp et al. (2008) and Damerow et al. (2007) for complete descriptions of the Darwin (a single spindle thinner) and Bonner (a three-rotor thinner).

y"Yes" indicates a significant difference $(P>0.05)$ reported between the control and a mechanical thinning treatment. "No" indicates that response variable was tested, but there was no difference between the control and any of the mechanical thinning treatments listed.

${ }^{x} \mathrm{NA}$ indicates that the study did not investigate the listed response variable.

"Spindle speed not presented.

${ }^{v}$ Statistical analysis not presented.

Kelderer, 1997; Weibel et al., 2008), but others found no effect (Damerow et al., 2007; Dorigoni et al., 2008; Hehnen et al., 2012). We found no relationship between thinning treatment and return bloom (Table 3 ). The high rates of spur removal observed in the previous season may have had a negative influence on return bloom. Our study used an annual bearing variety, and control trees were able to support a full crop in 2011 despite excessive croploads in 2010.

Fruit quality parameters generally benefitted from increased spindle speed (Table 4). Although increased spindle speed increased fruit firmness in our study, mechanical thinning did not improve fruit firmness in other experiments (Hehnen et al., 2012; Kong et al., 2009; Solomakhin and Blanke, 2010). Fruit firmness and soluble solids data were contradictory in both years. Because cropload was reduced as spindle speed increased, fruit maturity would be expected to be slightly accelerated. However, reduced competition among fruit may have delayed maturity, which resulted in increased firmness. Soluble solids increased as thinning severity increased, which accords with the results of Kong et al. (2009) and Solomakhin and Blanke (2010). In 2011, starch ratings and internal ethylene measurements were taken to elucidate the conflicting results observed between firmness and soluble solids in 2010 . Although starch rating was negatively correlated with increased spindle speed, internal ethylene concentration was unaffected by treatment (data not presented). 'Gala' is a low-ethylene apple, and there was no relationship between internal ethylene concentration and thinning treatments in 2011. Because all treatments had low to moderate croploads in 2011, relationships between spindle speed and internal ethylene concentration were not detected (data not presented). Some cultivars such as 'Gala' do not produce climacteric levels of ethylene until they are harvested. The "tree effect" may have contributed to low and variable ethylene levels (Lin and Walsh, 2008). Fruit were measured within $2 \mathrm{~d}$ of harvest, which may have been too early to detect climacteric ethylene levels (Larrigaudiere et al., 1997). As spindle speed increased, the result was a firmer, sweeter, more acidic, and starchier (less mature) fruit. The linear reduction in fruit calcium content with increased spindle speeds in both years of the study might be explained by the reduction of spur leaf tissue and resulting negative impacts on calcium allocation to fruit (Ferree and Palmer, 1982).

Comparing our work with recent mechanical thinning studies in the literature was difficult, because the type of thinning machine used, tractor speeds, spindle speeds, canopy shapes, and treatment structure varied widely. Table 5 presents a brief outline of several recent mechanical thinning studies to aid in comparing our work to the existing body of literature.

Severe treatments, 240 to $300 \mathrm{rpm}$, resulted in removal of entire spurs and a reduction in spur leaf area. We propose that damage to spur leaves was the most negative consequence of string thinning, because it may negatively influence fruit size and fruit calcium. Our data indicate that treatments of 180 and $210 \mathrm{rpm}$ with 90 strings at a tractor speed of $4.8 \mathrm{~km} \cdot \mathrm{h}^{-1}$ minimized spur leaf injury and provided the best overall thinning response. In a year of heavy fruit set, the level of thinning achieved at these lower spindle speeds was insufficient. In such years, mechanical thinning treatments could be supplemented with other thinning methods. Hand thinning or chemical thinning treatments in combination with early string thinner treatments have shown promise in enhancing fruit size in apple (Damerow et al., 2007; Dorigoni et al., 2008, 2010; Schupp et al., 2008; Sinatsch et al., 2010; Veal et al., 2011). The use of mechanical thinning treatments in combination with other thinning treatments should be pursued in future trials. We do not recommend use of the mechanical thinner as a solitary means of cropload management of apple.

\section{Literature Cited}

Baugher, T.A., J. Schupp, K. Lesser, and K. Reichard. 2009. Horizontal string blossom thinner reduces labor input and increases fruit size in peach trees trained to open-center systems. HortTechnology 19:755-761.

Bertschinger, L., W. Stadler, P. Stadler, F. Weibel, and R. Schumacher. 1998. New methods for an environmentally safe regulation of flower and fruit set and of alternate bearing of the apple crop. Acta Hort. 466:65-70.

Blanpied, G.D. and K.J. Silsby. 1992. Predicting harvest date windows for apples. Cornell Coop. Ext. Info. Bul. 221.

Damerow, L., A. Kunz, and M. Blanke. 2007 Regulation of fruit set by mechanical thinning. Erwerbs-Obstbau 49:1-9.

Dennis, F.G. 2000. The history of fruit thinning. Plant Growth Regulat. 31:1-16.

Dorigoni, A., N. Dallabetta, and P. Lezzer. 2008. Le alternative al carbaryl per il diradamento del melo. L'nformatore Agrario. 9:52-54.

Dorigoni, A., P. Lezzer, F. Micheli, N. Dallabetta, and J. Pasqualini. 2010. Diradare il melo a macchina: Cosa sapere per farlo bene. L'nformatore Agrario. 22:63-67.

Ferree, D.C. and J.W. Palmer. 1982. Effect of spur defoliation and ringing during bloom on fruiting, mineral level, and net photosynthesis of 'Golden Delicious' apple. J. Amer. Soc. Hort. Sci. 107:1182-1186.

Hehnen, D., I. Hanrahan, K. Lewis, J. McFerson, and M. Blanke. 2012. Mechanical flower thinning improves fruit quality of apple and promotes consistent bearing. Sci. Hort. 134: 241-244.

Huang, C.L. and E.E. Schulte. 1985. Digestion of plant tissue for analysis by ICP emission spectroscopy. Commun. Soil Sci. Plant Anal. 16: 943-958.

Kong, T., L. Damerow, and M.M. Blanke. 2009. Effect of mechanical thinning on ethylene efflux, yield, and fruit quality in apple. ErwerbsObstbau 51:39-52

Larrigaudiere, C., J. Graell, J. Salas, and M. Vendrell. 1997. Cultivar differences in the influence of a short period of cold storage on 
ethylene biosynthesis in apples. Postharvest Biol. Technol. 10:21-27.

Lin, S. and C. Walsh. 2008. Studies of the tree factor and its role in the maturation and ripening of 'Gala' and 'Fuji' apples. Postharvest Biol. Technol. 48:99-106.

Ngugi, H.K. and J.R. Schupp. 2009. Evaluation of the risk of spreading fireblight in apple orchards with a mechanical string blossom thinner. HortScience 44:862-865.

Saltveit, M.E. 1982. Procedures for extracting and analyzing internal gas samples from plant tissues by gas chromatography. HortScience 17:878-881.

Schupp, J.R., T.A. Baugher, S.S. Miller, R.M. Harsh, and K.M. Lesser. 2008. Mechanical thinning of peach and apple trees reduces labor input and increases fruit size. HortTechnology 18:660-670

Sinatsch, S., B. Pfeiffer, I. Toups, J. Zimmer, and B. Benduhn. 2010. Comparison of different thinning measures for organic grown apples. $14^{\text {th }}$ Intl. Conf. on Organic Fruit Growing. 14:200-205.

Solomakhin, A.A. and M.M. Blanke. 2010. Mechanical flower thinning improves fruit quality of apples. J. Sci. Food Agr. 90:735-741.

Stadler, W., L. Bertschinger, and F. Wiebel. 1996. Maschinelles ausdunnen-geeignet fur den umweltschonenden apfelanbau. Obst-Weinbau. 132:614-616.

Strimmer, M. and M. Kelderer. 1997. Neue auduennungsmethoden im biologischen apfelbau. Erwerbs-Obstbau 39:130-136.
Veal, D., L. Damerow, and M.M. Blanke. 2011. Selective mechanical thinning to regulate fruit set, improve quality and overcome alternate bearing in fruit crops. Acta Hort. 903:775782.

Weibel, F.P., V.S. Chevillat, E. Rios, J.L. Tschabold, and W. Stadler. 2008. Fruit thinning in organic apple growing with optimized strategies including natural spray products and rope-device. Europ. J. Hort. Sci. 73:145154.

Yuan, R. and D.W. Greene. 2000. Benzyladenine as a chemical thinner for 'McIntosh' apples. II. effects of benzyladenine, bourse shoot tip removal and leaf number on fruit retention. J. Amer. Soc. Hort. Sci. 125:177-182. 